\title{
Simply Put, I'm Tired: Efficacy to Combat Racism among African American Adolescent Boys and Girls
}

\author{
Phylicia C. Allen ${ }^{1} \cdot$ Sheretta T. Butler-Barnes $\mathbb{1}^{1} \cdot$ Helen Robinson ${ }^{1} \cdot$ Ashley Jackson ${ }^{1}$ \\ Accepted: 20 November 2021 / Published online: 11 January 2022 \\ (c) The Author(s), under exclusive licence to Springer Science+Business Media, LLC, part of Springer Nature 2021
}

\begin{abstract}
This study examined the mediating role of self-efficacy to combat racism on the effect of school-based racial discrimination and African American adolescents' racialized educational beliefs. Our study analyzed data from a total of 525 African American adolescents' boys $(N=256)$ and girls $(N=269)$. For African American boys and girls, teacher racial discrimination was associated with racialized educational beliefs, conceptualized by how hard African American adolescents believe they have to work in a school-based on their race. The results further revealed that for African American boys' selfefficacy to combat racial discrimination in school mediated the relationship between teacher and peer racial discrimination and racialized educational beliefs. However, for African American girls' self-efficacy to combat racial discrimination mediated the relationship between peer racial discrimination and racialized educational beliefs. The results did illustrate that feeling less self-efficacious to combat racial discrimination was associated with endorsing racialized educational beliefs for African American girls and boys. Research and practice implications are provided as well as the importance of considering gender differences amongst African American adolescents.
\end{abstract}

Keywords African American adolescents $\cdot$ Racial discrimination $\cdot$ Self-efficacy $\cdot$ Educational beliefs $\cdot$ Gender

\section{Highlights}

- Perceiving higher amounts of racial discrimination from teachers was associated with African American boys and girls endorsing beliefs that they have to work extra hard because of their race.

- Feeling less efficacious to combat racial discrimination was associated with higher racialized educational beliefs (e.g., working harder because you are Black).

- Perceiving higher levels of peer racial discrimination was associated with feeling less efficacious to combat racial discrimination for African American girls.

African American youth encounter up to five racial discrimination experiences per day (English et al. 2020). These racial discrimination encounters occur through interpersonal interactions and social media (English et al. 2020). In addition to these daily discriminatory interactions, African American adolescents are also encountering racial discrimination in educational settings. Thereby, the school context is especially important to consider because schools can either serve as a

Sheretta T. Butler-Barnes

sbarnes22@wustl.edu

1 Brown School of Social Work, Washington University in St. Louis, Campus Box 1196, St. Louis 63130 MO, USA promotive or inhibitive environment (Garcia-Coll et al. 1996). For instance, Leath et al., (2019) found that school-based racial discrimination was associated with lower levels of academic persistence and curiosity among African American adolescents. Moreover, spaces that promote educational hegemony (e.g., systemic oppression within an educational system) (Aguayo, 2019; Goodman \& West-Olatunji, 2010) create structures that limit educational opportunities for African American adolescents. These ideologies can influence the perspectives African American adolescents have about themselves and their learning opportunities (Banerjee et al., 2018; Leath et al., 2019). Because of the frequent exposure to racism (National Women's Law Center, 2014; Schott Foundation for Public Education, 2015; Williams-Washington \& Mills, 2018), it is imperative to understand the negative 
impact of racial discrimination on African Americans adolescents' educational beliefs.

It is also less clear from the literature how efficacious African American adolescents feel in combating racial discrimination in school. In other words, the extent to which African American youth feel as if they have the agency to avoid racial discrimination in school settings. Additionally, because of covert discrimination (e.g., concealed, or subtle racism; see Coates, 2008) and the unique experiences of African American adolescent boys and girls, we examine gendered experiences (Chavous et al., 2008; Leath et al., 2019; Mary et al. 2018; Rowley, et al., 2014). Thus, we seek to understand how school-based racial discrimination (i.e., teachers \& peers) predicts African American adolescents racialized educational beliefs and the mediating role of self-efficacious beliefs in combatting racism.

\section{Racial Discrimination and African American Boys}

There is a plethora of literature documenting the experiences that African American adolescent boys have with racial discrimination in school (Allen, 2015; Kunesh \& Noltemeyer, 2019; Rowley et al., 2014). Encounters with teacher racial discrimination as it relates to African American boys' educational experience is associated with lower academic performance (Allen, 2010; Chavous et al., 2008; Neblett et al., 2009; Thomas et al., 2009). For instance, Thomas and colleagues (2009) found a negative association between high levels of perceived teacher discrimination and academic achievement, indicating lower academic outcomes for African American boys perceiving constant discrimination. Chavous et al. (2008) examined an adolescent sample of African Americans to better understand schoolbased racial discrimination and academic engagement. While boys and girls had similar experiences with racial discrimination, boys reported experiencing peer and teacher discrimination more than girls. Cogburn et al., (2011) found that for African American boys, school-based racial discrimination was associated with lower GPAs, feeling that school was less important, and lower levels of self-esteem. Along these lines, the biases teachers have toward African American boys about being unteachable (Rowley et al., 2014) has resulted in the overrepresentation in special education and underrepresentation in gifted and advanced placement courses, placing them further behind their counterparts. Because African American boys are viewed as hostile, violent, and defiant (Allen, 2013; Monroe, 2005) teachers may overuse punitive and exclusionary discipline to reduce the perceived threat and control their behaviors (Caton, 2012; Howard, 2013; Rowley et al., 2014). Scholars also note that the increase in disciplinary action toward
African American boys is perpetuated because of biased school policies (Schott Foundation for Public Education, 2015), which confirms how systemic oppression is connected to individual actions and practices.

\section{Racial Discrimination and African American Girls}

In school, African American girls are faced with discriminatory encounters that have a negative impact on their educational experience (Carter Andrews et al., 2019; Hardaway et al., 2019; Woodson, 2020). For instance, African American girls are frequently berated by educators due to the misalignment of their behaviors when compared with the gender-based expectations other racial groups demonstrate (Carter Andrews et al., 2019). More specifically, Carter Andrews et al., (2019) found that in comparison to White girls, Black girls were often viewed as rowdy, disruptive, promiscuous, and not smart. Scholars have attributed these experiences to the views associated with African American girls as being angry and promiscuous (Harris-Perry, 2011), "loud," "hot mammas," and "having an attitude" (Joseph et al., 2016. p. 8), and these perceptions influence how teachers engage with them (National Women's Law Center, 2014). Thus, Black girls who do not conform to Whiteness are viewed as inferior and this contributes to the criminalization and exploitation of Black girls in schools (Epstein et al., 2017; Morris, 2016). As a result, Black girls are viewed as more likely to be disruptive and "unladylike" than White girls. For instance, White girls are more likely to be considered innocent and nonviolent than African American girls (Esposito \& Edwards, 2018; Morris, 2007). Morris (2007) found that African American girls were disciplined at higher rates than White girls, Latinx boys and girls, and Black boys; mostly because they were perceived as adequately feminine. The report All Teachers Should Be Trained to Overcome Their Hidden Biases, highlights a study focused on the biases that teachers have toward African American girls (Chemaly, 2015), indicating that African American girls are often penalized for being assertive in class. In this case, African American girls, "assertiveness" may be perceived as "anger" by teachers. Additionally, their assertiveness could be based on their aspirations to be leaders, yet teacher discrimination can hinder their goals (Butler-Barnes \& Inniss-Thompson, 2020; Morris, 2007; Morris, 2016; Morris \& Perry, 2017; National Women's Law Center, 2014; 2017). Assari and Caldwell (2018) found that for African American boys and girls, higher teacher discrimination was associated with lower school performance. However, African American girls had worse performance compared to boys when accounting for perceived teacher discrimination. 


\section{Self-Efficacy in Combating Racial Discrimination}

Self-efficacy is the human agency and belief one has around personal control to exercise capabilities and attain goals (Bandura, 1997). For this study, self-efficacy is captured as the level of efficacy and individual control African American adolescents perceive they must have to avoid and be impacted by racism from their teachers. Moreover, selfefficacy among Black youth in educational settings has been documented as an internal asset that improves academic achievement and may also serve as a buffer and coping mechanism against discrimination encouraging career advancement choices (Butler-Barnes et al., 2013; DeFreitas 2012; Kyere et al., 2021; Rollins \& Valdez, 2006). The literature around combating racial discrimination in schools has primarily focused on the role of teachers in creating antiracist environments (Kishimoto, 2018), and less on the ways in which youth develop the agency and self-efficacy to combat discrimination. Given the understanding that selfefficacy is supposed to be an asset that is empowering for individuals when it relates to racism, self-efficacy may not be present. No matter how self-efficacious African American adolescents may feel, due to the power dynamics between teachers and students, African American adolescents may not have enough control to combat these experiences or their impact. However, outside of the school context, while much of the literature shows promise in combating discrimination, the focus still centers on adults (Miller \& Donner, 2000; Young \& Laible, 2000). For instance, Gorski (2019) found that the cumulative effects of racism experienced during childhood inspired many activists to combat racism in adulthood. Thus, when youth are engaged in the designing of work aimed at addressing racism and discrimination, youth feel empowered and motivated (Hope et al., 2020). While these efforts are essential in addressing racism, we know less around the motivations of youth to engage in combating racial discrimination in the context of schools.

More importantly, a similar concept, racial battle fatigue has been used to understand the experiences of African American college students. Literature on racial battle fatigue explains that stress-related responses to racism are both psychological and physiological (Smith et al., 2007), and there is a process that individuals undergo whereby they interpret, analyze, and determine if they should or should not respond to racial discrimination (Hollingsworth et al., 2018; Smith et al., 2007). Research on racial battle fatigue indicates that to avoid the long-lasting effects of racial discrimination, African Americans may choose to combat experiences by minimizing them (Sue et al., 2008). The exhaustion from this may lead to racial battle fatigue (Pizzaro \& Kohli, 2018). For instance, in a qualitative study on the experiences of African American males at predominately
White institutions, stories illuminate that even in hostile/ racist environments African American males resist stigma and put that energy toward their academic goals (Hotchkins \& Dancy, 2015; Smith et al., 2007). Bailey-Fakhoury and Mitchell Jr. (2018), provide insight around the "veil", an intentional act of Black women protecting themselves from racial discrimination, and how this process induces racial battle fatigue. Overall, African American adolescents might have similar experiences, yet there is a dearth of research that examines the agency and the stress associated with students feeling like they cannot do much when exposed to discriminatory encounters in school.

\section{Guiding Framework}

We utilize the Integrative Model for the Study of Developmental Competencies in Minority Children (Garcia-Coll et al., 1996), because of our focus on African American adolescents' experiences with the teacher and peer-based racial discrimination and the impact on their racialized educational beliefs. This model focuses on social positions based on one's race, social class, ethnicity, and gender, and its relationship to experiences with racial discrimination. Additionally, it is important to examine how being embedded within certain environments may promote adverse or positive experiences that influence developmental competencies among minority children and youth. Aligning with the current study, this model also acknowledges school settings as an environment where racial discrimination may occur (Garcia-Coll et al., 1996) and may result in student resiliency or stagnation toward furthering their education. As racism occurs in these promotive and inhibiting environments, individuals make decisions about how to operate within these settings. For instance, individuals may feel efficacious in combating these experiences. Thus, the negative effect of racial discrimination in schools is minimized. Furthermore, the effects of teacher and peerbased racial discrimination are crucial to African American adolescent boys' and girls' educational journey. This model reflects how one's environment influences outcomes. Specifically, one's social position has an impact on how African American adolescent boys and girls navigate their social context. Consideration of this model proposes that African American adolescent boys and girls may experience teacher and peer-based racial discrimination in school and that the effects will influence their racialized educational beliefs.

\section{Current Study}

The current study examined the impact of school-based racial discrimination (i.e., teacher \& peer racial 
discrimination) on racialized educational beliefs. We were also interested in the mediational role of African American adolescent boys' and girls' self-efficacious beliefs in combating racial discrimination and the impact on racialized educational beliefs. Given the results from prior research studies, African American adolescent boys and girls are constantly confronted with racial discrimination (English et al., 2020; Hope et al., 2015), and these experiences have led to lower academic performance (Leath et al., 2019). We build on this work by examining self-efficacy to combat racial discrimination and how this shapes African American adolescent boys' and girls' educational beliefs. Thus, we hypothesized that: (1) African American adolescent boys and girls reports of perceived school-based racial discrimination (i.e., teacher \& peer racial discrimination) will be associated with higher racialized educational beliefs; (2) endorsing lower levels of self-efficacy to combat racial discrimination will be associated with higher levels of racialized educational beliefs, in other words, Black adolescents who feel as if they have little agency to avoid racial discrimination from either teacher or peers will be more likely to believe they have to work hard in school based on their race; and (3) self-efficacy to combat racial discrimination will mediate the relationships between schoolbased racial discrimination (i.e., teacher \& peer racial discrimination) and racialized educational beliefs for African American adolescent boys and girls.

\section{Method}

This study used data from the Maryland Adolescent Development in Context Study (MADICS) (see http://garp. education.uci.edu/madics.html). Beginning in 1991, the purpose of this longitudinal study was to examine how context influences behavior and successful pathways through adolescence 1480 African American (61\%) and European-American (35\%), adolescents and their families from rural, low income, and high-risk neighborhoods. The dataset includes a total of six waves of data focusing on the social contexts of youth including individual, family, and peer characteristics that influence youth development, youth involvement in extracurricular activities and how families managed them, race and ethnicity, an examination of peer relationships and overall wellbeing, and transitions to college and the workforce. In the current study, we use wave four in which African American adolescents were in their 11th grade high school year.

\section{Participants}

The present study examines the fourth wave of the MADICS data set, in which adolescents were in their 11th grade school year. The authors were interested in middle adolescence (ages 15 to 17) because peer relationships become more complex (Fabes et al., 2009). Additionally, adolescence is a critical time for identity development and is shaped by adolescents' schooling experiences (French et al., 2006). Thus, a total of 525 African American adolescents were in this wave. The final sample for the present study included African American female adolescents $(N=256)$ and African American male adolescents $(N=269)$ with complete data for all study variables. The mean age is 16.38 $(S D=2.00)$. The median household income level for the sample adolescents was $\$ 50,000-\$ 54,999$ (range $\$ 5000$ $\$ 200,000$ ). Detailed information about participants' community and school contexts can be found at the study website: http://garp.education.uci.edu/madics.html.

\section{Procedures}

The data was collected during adolescents' eleventh-grade year, through individual face-to-face interviews and a selfadministered questionnaire. The target adolescent and parent were interviewed for approximately $1 \mathrm{~h}$ each. Self-administered questionnaires took an average of $45 \mathrm{~min}$ to complete. Informed consent and assent were obtained from both parents and adolescents. In the current study, we used adolescents' report of their perceived school-based racial discrimination (i.e., teacher \& peer racial discrimination), self-efficacy to combat racial discrimination, and racialized educational beliefs. A review conducted by the Institutional Review Board (IRB) approved and determined the study to be compliant with the protection of the rights and welfare of human subjects.

\section{Measures}

\section{Teacher racial discrimination}

Perceived teacher racial discrimination was measured with a scale developed by the MADICS primary investigators. The measure assessed adolescents' perceptions of mistreatment from teachers based on their race. The scale consisted of four items. The items include: "Teachers call on you less because of your race", Teachers grade you harder because of your race", "You get disciplined more harsh because of your race", and "Teachers think you are less smart because of your race." The scale ranged from $1=$ never to $5=$ every day. Higher scores were indicative of more reports of teacher racial discrimination. Cronbach's alpha is 0.88 and 0.85 for girls and boys, respectively.

\section{Peer racial discrimination}

Perceived peer racial discrimination was measured with a scale developed by the MADICS primary investigators. 
Table 1 Mean and Correlation Table for Boys and Girls

\begin{tabular}{lllllll}
\hline & Boys & Girls & & & \\
& $M(S D)$ & $M(S D)$ & 1 & 2 & 3 & 4 \\
\hline 1. Efficacy to combat racial discrimination & $2.29(0.69)$ & $2.10(0.70)$ & - & $0.28^{* *}$ & $0.24^{* *}$ & $0.37^{* *}$ \\
2. Teacher racial discrimination & $1.61(0.81)$ & $1.27(0.58)$ & $0.12^{*}$ & - & $0.59^{* *}$ & $0.14^{* *}$ \\
3. Peer racial discrimination & $1.43(0.79)$ & $1.23(0.61)$ & $0.14^{*}$ & $0.64^{* *}$ & - & 0.08 \\
4. Racialized educational beliefs & $2.46(0.82)$ & $2.35(0.83)$ & $0.29^{* *}$ & $0.16^{* *}$ & $0.17^{* *}$ & - \\
\hline
\end{tabular}

Note. Mean family income is $\$ 50,000$ to $\$ 54,999$ for girls and $\$ 55,000$ to $\$ 59,999$ for boys

$* p<0.05, * * p<0.01$. Correlations for boys are above the diagonal and those for girls are below the diagonal
The measure assessed adolescents' perceptions of mistreatment from peers based on their race. The scale consisted of two items. The items include: "Not picked on for team/activity because of your race", "Kids don't hang out with you because of your race". The scale ranged from $1=$ never to $5=$ every day. Higher scores were indicative of more reports of peer racial discrimination. Cronbach's alpha is 0.77 and 0.80 for girls and boys, respectively.

\section{Self-efficacy in combating racial discrimination}

Self-efficacy to combat racial discrimination was measured with a scale developed by the MADICS primary investigators. Adolescents were asked: "There is little you can do to avoid racial discrimination at school," and "There is little you can do to avoid racial discrimination by your peers." The scale ranged from $1=$ strongly disagree to $4=$ strongly agree. Higher scores are indicative of less self-efficacy in combating racial discrimination. Cronbach's alpha for boys and girls were 0.63 and 0.71 , respectively.

\section{Racialized educational beliefs}

Adolescents racialized educational beliefs with items developed by the MADICS primary investigators. These items assessed youth's views about differences in achievement based on their race, including "Because of your race, no matter how hard you work, you will always have to work harder than others to prove yourself," and "Because of your race, it is important that you do better than other kids at school in order to get ahead." Responses ranged from $1=$ strongly disagree to $4=$ strongly agree." Higher scores were indicative of endorsing higher racialized educational beliefs. Cronbach's alpha for boys and girls are 0.72 and 0.81 , respectively.

\section{Data Analytic Plan}

The statistical software package, IMB SPSS Statistics v.27.0 (IBM, Corp., 2020) was used to analyze the data. To test our primary study hypotheses, a mediation analysis was conducted to assess whether efficacy to combat racial discrimination mediated the relationship between racial discrimination (i.e., perceived unfair treatment from teachers and peers) and racialized educational beliefs. For these analyses, we used PROCESS SPSS Macro version 3.5, model 4 with 5000 bias-corrected bootstrap samples (Hayes, 2012). Mediation effects were assessed by the indirect effect of teacher and peer racial discrimination (independent variable) on racialized educational beliefs (outcome) through efficacy to combat racial discrimination (mediator). The total indirect effects (IE) with $95 \%$ confidence intervals are reported.

\section{Results}

Data in Table 1 include the means and correlations of the primary variables of the study. Mean scores for African Americans reveal that on average African American adolescent boys and girls experience some teacher and peer racial discrimination, feeling moderately efficacious in combatting racism, and believe that because of their race they'll have to work harder than others.

Correlational analyses indicated significant positive relationships between teacher racial discrimination, peer racial discrimination, self-efficacy to combat racism, and racialized educational beliefs for African American boys. More specifically, feeling less self-efficacious to combat racial discrimination was associated with endorsing higher levels of racial discrimination (i.e., teacher \& peers) for Black boys. Similar findings were found for African American girls, with feelings of less self-efficacy to combat racial discrimination being associated with higher levels of racial discrimination from teachers and peers. Lastly, for African American girls, reports of higher levels of peer racial discrimination were associated with endorsing more racialized educational beliefs (see Table 1).

\section{Mediation Analysis}

Mediation analysis was conducted with PROCESS SPSS Macro version 3.5, using model 4 to examine how adolescent boys and girls reports of self-efficacy to combat racial discrimination mediated the relationship between perceived 
school-based racial discrimination (i.e., teacher \& peer racial discrimination) and racialized educational beliefs. The bootstrapping method of 5000 was utilized to estimate the standard errors for the indirect effects. For African American boys, perceiving higher levels of teacher racial discrimination was associated with feeling less efficacious to combat racial discrimination $(B=0.24, p=0.001), 95 \% \mathrm{CI}$ $[0.1468,0.3499], \beta=0.28, p<0.001$. Feeling less efficacious to combat racial discrimination was associated with higher racialized educational beliefs (e.g., working harder because you are Black) $(B=0.42, p=0.001), 95 \%$ CI $[0.2872,0.5721], \beta=0.36, p<0.001$. Teacher racial discrimination was not significantly associated with racialized educational beliefs $(B=0.03, p=0.58), 95 \%$ CI $[-0.0886$, $0.1560], \beta=0.03, p>0.05$. Similarly, perceiving higher levels of peer racial discrimination was associated with feeling less efficacious to combat racial discrimination $(B=$ $0.21, p=0.001), 95 \%$ CI [0.1276, 0.3372], $\beta=0.26, p<$ 0.001 . Feeling less efficacious to combat racial discrimination was associated with higher racialized educational beliefs (e.g., working harder because you are Black) $(B=0.44, p=0.001), 95 \%$ CI $[0.3063,0.5892], \beta=0.28$, $p<0.001$. Peer racial discrimination was not significantly associated with racialized educational beliefs $(B=-0.01$, $p=0.94), 95$ CI $[-0.1469,0.1020], \beta=-0.02, p>0.05$.

For African American girls, perceiving higher levels of teacher racial discrimination was associated with feeling less efficacious to combat racial discrimination $(B=0.14$, $p=0.045), 95 \%$ CI [0.0029, 0.2933], $\beta=0.12, p<0.05$. Feeling less efficacious to combat racial discrimination was associated with higher racialized educational beliefs (e.g., working harder because you are Black) $(B=0.32, p=$ $0.001), 95 \%$ CI $[0.1941,0.4651], \beta=0.28, p<0.001$. Teacher racial discrimination was significantly associated with endorsing higher racialized educational beliefs $(B=$ $0.18, p=0.031) 95 \%$ CI $[0.0161,0.3452], \beta=0.12, p<$ 0.001 . Additionally, perceiving higher levels of peer racial discrimination was associated with feeling less efficacious to combat racial discrimination $(B=0.20, p=0.012), 95 \%$ CI [0.0436, 0.3588], $\beta=0.15, p<0.05$. Feeling less efficacious to combat racial discrimination was associated with higher racialized educational beliefs (e.g., working harder because you are Black) $(B=0.32, p=0.001), 95 \%$ CI $[0.1925,0.4655], \beta=0.27, p<0.001$. Peer racial discrimination was not significantly associated with racialized educational beliefs $(B=0.16, p=0.07), 95 \%$ CI $[-0.0174$, 0.3438 ], $\beta=0.10, p<0.05$.

\section{The Mediational Role of Self-Efficacy to Combat Racial Discrimination}

We tested for meditation effects by examining the indirect effects of perceived teacher and peer racial discrimination

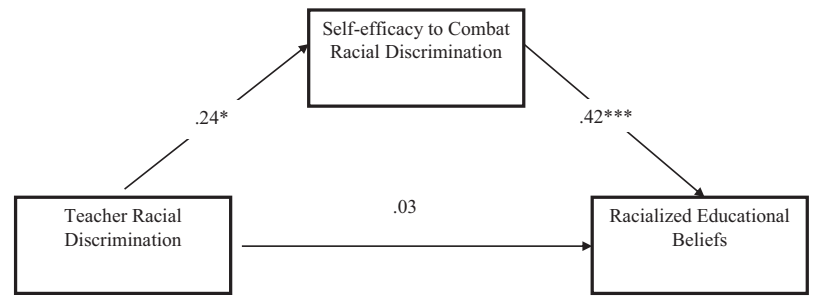

Fig. 1 The mediational role of self-efficacy to combat racial discrimination for African American adolescent boys. Note. $* * * p<0.01$

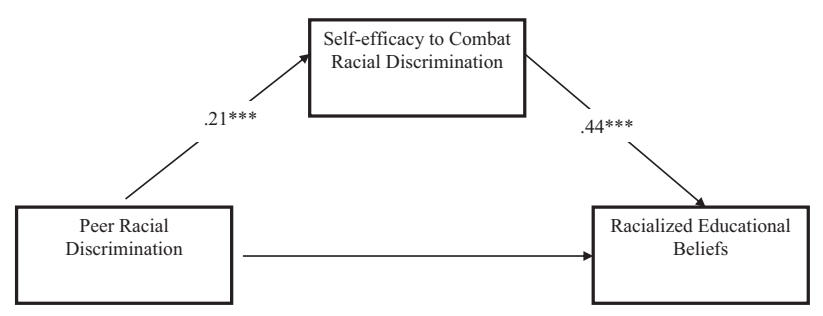

Fig. 2 The mediational role of self-efficacy to combat racial discrimination for African American adolescent boys. Note. $* * * p<0.01$

on racialized educational beliefs via self-efficacy to combat racial discrimination. The findings revealed indirect effects of teacher (indirect $=0.11, S E=0.03,95 \%$ CI $[0.051$, $0.179]$ ) and peer (indirect $=0.10, \mathrm{SE}=0.03,95 \% \mathrm{CI}$ $[0.043,0.156])$ racial discrimination through self-efficacy to combat racial discrimination on racialized educational beliefs for African American boys (see Figs. 1 and 2). These results support mediation. School-based teacher racial discrimination was no longer a significant predictor of racialized educational beliefs after controlling for the mediator, efficacy to combat racial discrimination $(B=0.03, p=$ $0.58), 95 \%$ CI $[-0.0886,0.1560], \beta=0.03, p>0.05$, consistent with full mediation for both models.

For Black girls, self-efficacy for combat racial discrimination did not mediate the relationship between perceived teacher racial discrimination and racialized educational beliefs for African American girls (see Fig. 3). However, self-efficacy to combat racial discrimination mediated the relationship between peer racial discrimination and racialized educational beliefs (indirect $=0.07, S E=$ $0.03,95 \%$ CI $[0.020,0.127])$, consistent with full mediation (see Fig. 4).

\section{Discussion}

This study examined the relationship between school-based racial discrimination and African American adolescents racialized educational beliefs. The study also examined the mediating role of self-efficacy to combat racism. Gender differences were also explored. The findings revealed that efficacy to combat racism mediated the relationship 


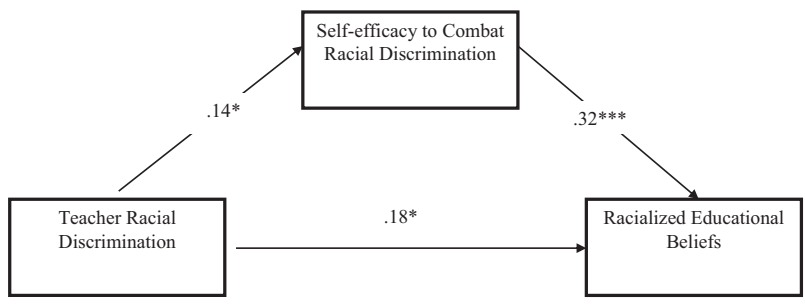

Fig. 3 The mediational role of self-efficacy to combat racial discrimination for African American adolescent girls. Note. $* p<0.05$, $* * * p<0.001$

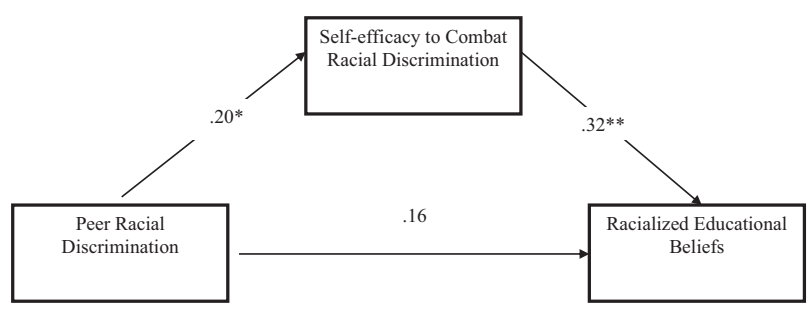

Fig. 4 The mediational role of self-efficacy to combat racial discrimination for African American adolescent girls. Note. $* * p<0.01$ $* * p<0.010$

between peer and teacher-based racial discrimination and racialized educational beliefs for African American boys. For African American girls, efficacy to combat racism mediated the relationship between school-based peer racial discrimination and racialized educational beliefs.

The similarities between African American boys and girls in our study were that (1) feeling less efficacious to combat racial discrimination was associated with endorsing higher racialized educational beliefs and (2) racial discrimination from teachers and peers was associated with feeling less efficacious to combat racial discrimination. The one difference between African American girls and boys in this study was that there was a direct effect of teacher racial discrimination on Black girls' educational beliefs. These findings corroborate the increasing literature on Black girls racialized and gendered experiences within the classroom (e.g., Butler-Barnes \& Inniss-Thompson, 2020; Carter Andrews et al., 2019; Hardaway et al., 2019; Woodson, 2020). For instance, Butler-Barnes \& Inniss-Thompson, 2020 found that among a nationally representative sample of Black American girls, perceived teacher discrimination was associated with higher disciplinary infractions. Moving forward, to understand the unique racialized experiences of Black girls and Black boys, centering youth voice is imperative to understand the extent to which these negative encounters in the classroom (Butler, 2018; Dumas \& Nelson, 2016) impact learning outcomes.

Additionally, for African American boys and girls, less self-efficacy to combat racial discrimination was associated with endorsements of working harder because of one's race. These findings have implications not only for youth education but wellbeing outcomes. For instance, research has found that reports of race-related stress are associated with higher reports of depressive symptomatology and anxiety among African American adults (Carter et al., 2011; Greer et al., 2009; Jones et al., 2007; Odafe et al., 2017). In the few studies that have examined Black adolescents it was found that higher reports of race-related stress are associated with risky behavior for African American boys (StevensWatkins et al., 2011). Despite the dearth of research, scholars have begun to note the importance of examining racerelated stressors among adolescents (Anderson et al., 2019; Jones \& Neblett, 2017; Jones et al., 2020). Future research should examine the efficacy to combat racial discrimination (e.g., feeling less efficacious) as a potential race-related stressor for African American youth. It is also less clear as to how feeling more efficacious to combat racial discrimination would benefit African American youth. However, it is plausible that feeling highly efficacious to combat racial discrimination could promote civic engagement in African American youth (Hope et al., 2019). It is also important to note that these findings have implications on racial battle fatigue syndrome. For instance, research on racial battle fatigue indicates that in an effort to avoid the long-lasting effects of racial discrimination, African Americans may choose to combat experiences by minimizing them (Sue et al., 2008). In our study, it might be the case that African American adolescents experiencing higher levels of racial discrimination from teachers and peers feel powerlessness.

Overall, the current study adds to the literature by considering the racialized stressors (Gibbons et al., 2012; Jones et al., 2020) that African American adolescents experience because of perceived teacher and peer racial discrimination. The effect of this encounter in addition to an adolescent feeling as though they cannot protect themselves from experiencing racial discrimination is so strong it can change African Americans adolescents' perspectives about their education and what education means for them because of their race-these experiences can be taxing not only for African American adults (see Smith et al., 2007) but for African American adolescents. Additionally, based on Garcia-Coll et al., (1996) Integrative Model for the Developmental Competencies of Minority Children, context matters. Furthermore, the intersectional experiences of African American adolescents' (e.g., race, class, $\&$ gender) warrant promoting racial and gender equity policies in school settings and are crucial for positive youth development. Because school settings can promote or hinder positive youth development, it is imperative to understand how these settings impact Black youth's wellbeing.

\section{Limitations and Future Directions}

For this study, African American adolescents shared the extent to which they believed they could avoid racial discrimination. 
This study is a major contribution to the field given the dearth of literature examining the internal struggle African American adolescents face in responding to schoolbased racial discrimination (i.e., teacher \& peer). Still, there are a few limitations. First, this study draws from one wave of data when adolescents were in the 11th grade. As such, scholars should incorporate longitudinal data analysis to assess experiences over time. We know that adolescents perceive racial discrimination at an early age, thus, understanding if age contributes to their beliefs is important to consider. A limitation of the study is the use of the MADICS data set because it was collected in the early 1990s. While it is possible that the experiences of racial discrimination vary, racial discrimination is still impacting African American youth in the present day. Because African American adolescents encounter on average five racial discrimination experiences per day (English et al. 2020), this can be harmful to African American adolescents learning and wellbeing. Nationally, reports such as Let her Learn (National Women's Law Center, 2018) and the Schott Foundation Report (2015) have noted the negative experiences of African American girls and boys, respectively. These experiences have also been revealed through social media (e.g., discriminatory hair and dress policies). Thus, despite the data collection year of this study, our findings underscore the negative impact of racial discrimination and have implications for present school practices and policies. Regarding peerbased racial discrimination, future research should examine the frequency and type of racial discrimination African American adolescents perceive from their peers. For instance, Douglass et al. (2016) found that "ethnicracial teasing" from peers, which was characterized by making jokes, was associated with higher anxiety levels among a sample of racially and ethnically diverse adolescents. Our study examines the extent to which Black adolescents reported being excluded. Future research should continue to understand the nuances of peer-based racism that Black adolescents encounter.

This area of research could also be strengthened by including data on teacher preparation in racial and ethnically diverse school settings. Implications of this may include culturally relevant programs and interventions that prepare teachers to engage with students no matter their racial differences. Additionally, Howard (2003) suggests teacher facilitation of culturally relevant instruction that is relevant to the lives of African Americans. It is also known that racial and ethnically diverse settings are not indicative of classroom or teacher makeup. Our dataset does not have information about the race of the teacher. Future work would also benefit from also examining the adolescents' interactions with administration and additional staff within the school building.
Additionally, despite examining African American boys and girls perceived teacher and peer racial discrimination, it is also important to note the important role of additional social identities. For instance, for Black adolescent girls, they comprise two marginalized identities (race \& gender). What is the extent to which they are experiencing gendered racism (see Thomas et al., 2008)? Future research should also consider the unique role of intersectionality and how additional social identities (e.g., LGBT) shape their experiences within the classroom.

\section{Moving Forward: Anti-Racism Training in Urban Education}

Addressing inequities is imperative in understanding how negative racialized experiences within the classroom shape the educational trajectory of African American adolescents. In our study, we included a sample of a socioeconomically diverse sample of American adolescents who reported perceiving school-based racial discrimination, which impacted their educational beliefs. How do we as a society deal with racism within the classroom? What constructive conversations about racism and bias can occur within schools? Kailin $(1998,2002)$ underscored the importance of preparing teachers to take an anti-racist lens. In that, several aspects of the climate must be addressed. One of these aspects is the social context of teaching and teacher education. By taking a critical examination of the teaching profession as being highly racialized is imperative. For instance, according to the U.S. Department of Education, National Center for Education Statistics (NCES) (20112012), $82 \%$ of teachers in public elementary and secondary schools were White. This presents a challenge when the student populations within schools are becoming increasingly racially and ethnically diverse (de Brey et al., 2019). Siddle-Walker (2000) and Milner (2006) noted the positive impact that Black teachers have on Black students' academic success. Gershenson et al., (2018) also found that same-race teachers were associated with higher academic success for Black children and adolescents. Non-racist practices and culturally relevant teaching is also critical component. Ladson-Billings (2009) found that teachers supporting and allowing children to embrace their own culture and lived experiences was a transformative experience for both teachers and students. Thus, anti-racist training can be a source of education and transformation within the classroom that reduces the negative racial stereotypes that teachers have about children of color. Thus, allowing for reflection and transformation by examining unconscious biases, the social construction of Whiteness, and the racist practices and policies that are systemic. Because of the detrimental impact of racism on the educational beliefs of African American adolescents, anti-racist training in urban 
education reveals the social, economic, psychological, and political conditions that shape the learning outcomes of oppressed and marginalized populations. Our study contributes to this work, by examining the deleterious impact of school-based racial discrimination on the educational beliefs of African American adolescents. Additionally, the most important finding from this study is that African American adolescents feeling less efficacious to combat racial discrimination endorsed higher racialized beliefs, in other words, believing that because of their racialized status they would have to work harder in proving their self-worth. However, those feeling more efficacious were less likely to endorse racialized educational beliefs. In general, promoting an anti-racist framework can reduce the stress associated with adolescents' efficacious beliefs in combating racial discrimination within classrooms that can be disruptive to African American adolescents' learning. Future studies are necessary to better understand the experiences within classrooms and how anti-racist training can enhance the educational and socio-emotional outcomes of African American adolescents.

\section{Conclusion}

Results from the current study show that African American adolescents who reported feeling less efficacious to combat racial discrimination reported higher racialized educational beliefs. In other words, feeling less efficacious to combat racial discrimination causes African American adolescent boys and girls to believe that because of their race they must work harder. These findings have implications on how we study racial battle fatigue and stereotype threat. Both literatures have largely been examined within college samples (e.g., Appel \& Kronberger, 2012; Smith, 2014; Smith et al., 2011a; Smith et al., 2011b). Future research should also consider the role of self-efficacy to combat racial discrimination and the role for African American adolescents in settings where they have little to no power. For instance, in our study, we also found that perceiving higher levels of teacher racial discrimination was associated with adolescents feeling less efficacious to combat racial discrimination. Taking a developmental perspective, how does feeling less efficacious to combat racism and perceiving teacher racial discrimination shape Black adolescents' educational trajectory over time? These ongoing interactions between adolescents and teachers likely lead adolescents to develop negative expectations for future interactions on which adolescents may base their interpretations of the educational system as being less supportive. In conclusion, the results of this study contribute to the dearth of research in understanding the role of self-efficacy in combating racial discrimination among African American adolescents and the impact on their educational beliefs. Research exploring variations in how Black adolescents cope with racism will further our understanding of the many ways that African American adolescents experience their school's settings and the implications on academic achievement. More importantly, interventions that center youth voice and promote healing from racial trauma and stress are imperative to promote healthy wellbeing among Black youth (Anderson et al., 2019).

Author Contributions P.C.A. and S.B.B. conceived of the study, participated in the research design, and drafted the manuscript. S.B.B. performed statistical analyses and interpretation of the data. A.J. and H.B. helped to draft the manuscript. All authors read and approved the final manuscript.

Funding This work was supported in part by the NICHD Grant \#R01 HD33437, NICHD Grant \# R01 HD048970, and NICHD Grant \# R01 HD068298.

\section{Compliance with Ethical Standards}

Conflict of Interest The authors declare no competing interests.

Consent to Participate Informed consent and assent were obtained from all participants in the study.

Publisher's note Springer Nature remains neutral with regard to jurisdictional claims in published maps and institutional affiliations.

\section{References}

Aguayo, D. (2019). Dismantling racism in public schools using critical race theory and Whiteness studies. Urban Education, 54(5), 764-771. https://doi.org/10.1177/0042085918783822.

Allen, Q. (2010). Racial microaggressions: The schooling experiences of Black middle-class males in Arizona's secondary schools. Journal of African American Males in Education (JAAME), 1(2), 125-143.

Allen, Q. (2013). "They think minority means lesser than" Black middle-class sons and fathers resisting microaggressions in the school. Urban Education, 48(2), 171-197. https://doi.org/10. $1177 / 0042085912450575$.

Allen, Q. (2015). Race, culture and agency: examining the ideologies and practices of US teachers of black male students. Teaching and Teacher Education, 47, 71-81. https://doi.org/10.1016/j.tate. 2014.12.010.

Anderson, R. E., McKenny, M. C., \& Stevenson, H. C. (2019). EMBRace: developing a racial socialization intervention to reduce racial stress and enhance racial coping among Black parents and adolescents. Family Process, 58(1), 53-67. https:// doi.org/10.1111/famp. 12412 .

Appel, M., \& Kronberger, N. (2012). Stereotypes and the achievement gap: Stereotype threat prior to test taking. Educational Psychology Review, 24(4), 609-635. https://doi.org/10.1007/s10648-0129200-4.

Assari, S., \& Caldwell, C. (2018). Teacher discrimination reduces school performance of African American youth: role of gender. Brain Sciences, 8(10), 183. https://doi.org/10.3390/bra insci8100183. 
Butler-Barnes, S. T., Chavous, T. M., Hurd, N., \& Varner, F. (2013). African American adolescents' academic persistence: A strengths-based approach. Journal of Youth and Adolescence, 42(9), 1443-1458. https://doi.org/10.1007/s10964-013-9962-0.

Butler-Barnes, S. T., \& Inniss-Thompson, M. N. (2020). "My Teacher Doesn't Like Me": Perceptions of Teacher Discrimination and School Discipline among African-American and Caribbean Black Adolescent Girls. Education Sciences, 10(2), 44. https://doi.org/ 10.3390/educsci10020044.

Bailey-Fakhoury, C., \& Mitchell, D. (2018). LIVING WITHIN THE VEIL: How Black Mothers with Daughters Attending Predominantly White Schools Experience Racial Battle Fatigue When Combating Racial Microaggressions. Du Bois Review: Social Science Research on Race, 15(2), 489-515. https://doi.org/ 10.1017/S1742058X1800022X.

Banerjee, M., Byrd, C., \& Rowley, S. (2018). The relationships of school-based discrimination and ethnic-racial socialization to African American adolescents' achievement outcomes. Social Sciences, 7(10), 208. https://doi.org/10.3390/socsci7100208.

Bandura, A. (1997) Self-efficacy: the exercise of control. W H Freeman/Times Books/ Henry Holt \& Co.

Butler, T. T. (2018). Black girl cartography: black girlhood and placemaking in education research. Review of Research in Education, 42(1), 28-45. https://doi.org/10.3102/0091732X18762114.

Carter Andrews, D. J., Brown, T., Castro, E., \& Id-Deen, E. (2019). The impossibility of being "perfect and white": black girls' racialized and gendered schooling experiences. American Educational Research Journal, 56(6), 2531-2572. https://doi.org/10. 3102/0002831219849392.

Carter, R. T., \& Reynolds, A. L. (2011). Race-related stress, racial identity status attitudes, and emotional reactions of Black Americans. Cultural Diversity and Ethnic Minority Psychology, 17(2), 156-162. https://doi.org/10.1037/a0023358.

Caton, M. T. (2012). Black male perspectives on their educational experiences in high school. Urban Education, 47(6), 1055-1085. https://doi.org/10.1177/0042085912454442.

Chavous, T. M., Rivas-Drake, D., Smalls, C., Griffin, T., \& Cogburn, C. (2008). Gender matters, too: the influences of school racial discrimination and racial identity on academic engagement outcomes among African American adolescents. Developmental Psychology, 44, 637-654. https://doi.org/10.1037/0012-1649.44.3.637.

Chemaly, S. (2015). All teachers should be trained to overcome their hidden biases. Time. Available at http://time.com/3705454/tea chers-biases-girls-education/.

Coates, R. D. (2008). Covert racism in the USA and globally. Sociology Compass, 2(1), 208-231. https://doi.org/10.1111/j. 1751-9020.2007.00057.x.

Cogburn, C. D., Chavous, T. M., \& Griffin, T. M. (2011). Schoolbased racial and gender discrimination among African American adolescents: Exploring gender variation in frequency and implications for adjustment. Race and Social Problems, 3(1), 25 https://doi.org/10.1007/s12552-011-9040-8.

de Brey, C., Musu, L., McFarland, J., Wilkinson-Flicker, S., Diliberti, M., Zhang, A.,... \& Wang, X. (2019). Status and trends in the education of racial and ethnic groups 2018. NCES 2019-038. National Center for Education Statistics.

DeFreitas, S. C. (2012). Differences between African American and European American first-year Garcia-College students in the relationship between self-efficacy, outcome expectations, and academic achievement. Social Psychology of Education, 15(1), 109-123. https://doi.org/10.1007/s11218-011-9172-0.

Douglass, S., Mirpuri, S., English, D., \& Yip, T. (2016). "They were just making jokes": ethnic/racial teasing and discrimination among adolescents. Cultural Diversity and Ethnic Minority Psychology, 22(1), 69-82. https://doi.org/10.1037/ cdp0000041.
Dumas, M. J. \& Nelson, J. D. (2016). (Re)Imagining Black Boyhood: Toward a Critical Framework for Educational Research. Harvard Educational Review, 86(1), 27-47. https://doi.org/10.17763/ 0017-8055.86.1.27.

English, D., Lambert, S. F., Tynes, B. M., Bowleg, L., Zea, M. C., \& Howard, L. C. (2020). Daily multidimensional racial discrimination among Black US American adolescents. Journal of Applied Developmental Psychology, 66, 101068. https://doi.org/ 10.1016/j.appdev.2019.101068.

Epstein, R., Blake, J., \& González, T. (2017). Girlhood interrupted: the erasure of Black girls' childhood. Available at SSRN 3000695.

Esposito, J., \& Edwards, E. B. (2018). When black girls fight: interrogating, interrupting, and (Re)imagining dangerous scripts of femininity in urban classrooms. Sociology of Race and Ethnicity, 50(1), 264-277. https://doi.org/10.1177/2332649220933307.

Fabes R. A., Martin C. L., Hanish L. D. (2009). Handbook of peer interactions, relationships, and groups. Children's behaviors and interactions with peers. (pp. 45-62). New York: Guilford Press.

French, S. E., Seidman, E., Allen, L., \& Aber, J. L. (2006). The development of ethnic identity during adolescence. Developmental Psychology, 42(1), 1-10. https://doi.org/10.1037/00121649.42.1.1.

Garcia-Coll, C., Lamberty, G., Jenkins, R., Pipes McAdoo, H., Crnic, K., Hanna Wasik, B., \& Vazquez Garcia, H. (1996). An integrative model for the study of developmental competencies in minority children. Child Development, 67, 1891-1914. https:// doi.org/10.2307/1131600.

Gershenson, S., Hart, C., Hyman, J., Lindsay, C., \& Papageorge, N. W. (2018). The long-run impacts of same-race teachers (No. w25254). National Bureau of Economic Research.

Gibbons, F. X., Roberts, M. E., Gerrard, M., Li, Z., Beach, S. R. H., Simons, R. L., Weng, C.-Y., \& Philibert, R. A. (2012). The impact of stress on the life history strategies of African American adolescents: Cognitions, genetic moderation, and the role of discrimination. Developmental Psychology, 48(3), 722-739. https://doi.org/10.1037/a0026599.

Goodman, R. D., West-Olatunji, C. A. (2010). Educational hegemony, traumatic stress, and African American and Latino students. Journal of Multicultural Counseling and Development, 38, 176-186. https://doi.org/10.1002/j.2161-1912.2010.tb00125.x

Greer, T. M., Laseter, A., \& Asiamah, D. (2009). Gender as a moderator of the relation between race-related stress and mental health symptoms for African Americans. Psychology of Women Quarterly, 33 (3), 295-307. https://doi.org/10.1177/036168430903300305.

Gorski, P. C. (2019). Fighting racism, battling burnout: causes of activist burnout in US racial justice activists. Ethnic and Racial Studies, 42(5), 667-687. https://doi.org/10.1080/01419870.2018. 1439981.

Hayes, A. F. (2012). PROCESS: A versatile computational tool for observed variable mediation, moderation, and conditional process modeling.

Hardaway, A. T., Ward, L. W., \& Howell, D. (2019). Black girls and womyn matter: Using Black feminist thought to examine violence and erasure in education. Urban Education Research \& Policy Annuals, 6(1), 31-46.

Harris-Perry, M. V. (2011). Sister citizen: shame, stereotypes, and black women in America. New Haven: Yale University Press.

Hollingsworth, L. D., Patton, D. U., Allen, P. C., \& Johnson, K. E. (2018). Racial microaggressions in social work education: Black students' encounters in a predominantly White institution. Journal of Ethnic \& Cultural Diversity in Social Work, 27(1), 95-105.

Hotchkins, B. K., \& Dancy, T. E. (2015). Black male student leaders in predominantly White universities: Stories of power, preservation, and persistence. Western Journal of Black Studies, 39(1), 30.

Hope, E. C., Skoog, A. B., \& Jagers, R. J. (2015). "It'll never be the White Kids, it'll always be us" Black high school students' 
evolving critical analysis of racial discrimination and inequity in schools. Journal of Adolescent Research, 30(1), 83-112. https:// doi.org/10.1177/0743558414550688.

Hope, E. C., Gugwor, R., Riddick, K. N., \& Pender, K. N. (2019). Engaged against the machine: Institutional and cultural racial discrimination and racial identity as predictors of activism orientation among Black youth. American Journal of Community Psychology, 63(1-2), 61-72. https://doi.org/10.1002/ajcp.12303.

Hope, E. C., Smith, C. D., Cryer-Coupet, Q. R., \& Briggs, A. S. (2020). Relations between racial stress and critical consciousness for black adolescents. Journal of Applied Developmental Psychology, 70, 101184. https://doi.org/10.1016/j.appdev.2020.101184.

Howard, T. C. (2003). Culturally relevant pedagogy: Ingredients for critical teacher reflection. Theory into Practice, 42(3), 195-202. https://doi.org/10.1207/s15430421tip4203_5.

Howard, T. C. (2013). How does it feel to be a problem? Black male students, schools, and learning in enhancing the knowledge base to disrupt deficit frameworks. Review of Research in Education, 37(1), 54-86. https://doi.org/10.3102/0091732X12462985.

IBM Corp. Released 2020. IBM SPSS Statistics for Windows, Version 27.0. Armonk, NY: IBM Corp

Jones, H. L., Cross, W. E., \& DeFour, D. C. (2007). Race-related stress, racial identity attitudes, and mental health among black women. Journal of Black Psychology, 33(2), 208-231. https:// doi.org/10.1177/0095798407299517.

Joseph, N. M., Viesca, K. M., \& Bianco, M. (2016). Black female adolescents and racism in schools: Experiences in a colorblind society. The High School Journal, 100(1), 4-25. https://doi.org/ 10.1353/hsj.2016.0018.

Kailin, J. (1998). Preparing urban teachers for schools and communities: an anti-racist perspective. The High School Journal, 82(2), $80-87$.

Kailin, J. (2002). Antiracist education: from theory to practice. Rowman \& Littlefield.

Kishimoto, K. (2018). Anti-racist pedagogy: from faculty's selfreflection to organizing within and beyond the classroom. Race Ethnicity and Education, 21(4), 540-554. https://doi.org/10.1080/ 13613324.2016.1248824.

Kunesh, C. E., \& Noltemeyer, A. (2019). Understanding disciplinary disproportionality: stereotypes shape pre-service teachers' beliefs about black boys' behavior. Urban Education, 54(4), 471-498. https://doi.org/10.1177/0042085915623337.

Kyere, E., Fukui, S., \& Holly Jr., J. (2021). Fostering higher academic performance in African American youth through enhanced selfefficacy: the importance of integrated racial-ethnic identity. Journal of Higher Education Theory and Practice, 21(7), 20-33. https://doi.org/10.33423/jhetp.v21i7.4483.

Jones, S. C. T., Anderson, R. E., Gaskin-Wasson, A. L., Sawyer, B. A., Applewhite, K., \& Metzger, I. W. (2020). From "crib to coffin": navigating coping from racism-related stress throughout the lifespan of Black Americans. American Journal of Orthopsychiatry, 90(2), 267-282. https://doi.org/10.1037/ort0000430.

Jones, S. C., \& Neblett, E. W. (2017). Future directions in research on racism-related stress and racial-ethnic protective factors for Black youth. Journal of Clinical Child \& Adolescent Psychology, 46(5), 754-766. https://doi.org/10.1080/15374416.2016.1146991.

Ladson-Billings, G. (2009). The dreamkeepers: Successful teachers of African American children. John Wiley \& Sons.

Leath, S., Mathews, C., Harrison, A., \& Chavous, T. (2019). Racial identity, racial discrimination, and classroom engagement outcomes among black girls and boys in predominantly black and predominantly White school districts. American Educational Research Journal, 56(4), 1318-1352. https://doi.org/10.3102/ 0002831218816955.

Mary, J. S., Calhoun, M., Tejada, J., \& Jenson, J. M. (2018). Perceptions of academic achievement and educational opportunities among Black and African American youth. Child and Adolescent Social Work Journal, 35(5), 499-509. https://doi.org/10.1007/ s10560-018-0538-4.

Miller, J., \& Donner, S. (2000). More than just talk: The use of racial dialogues to combat racism. Social work with groups, 23(1), 31-53. https://doi.org/10.1300/J009v23n01_03.

Milner, IV, H. R. (2006). The promise of black teachers' success with black students. Educational Foundations, 20, 89-104.

Monroe, C. R. (2005). Why are "bad boys" always Black? Clearing House, 79(1), 45-50. https://doi.org/10.3200/TCHS.79.1.45-50.

Morris, E. W. (2007). "Ladies" or "Loudies"? Perceptions and experiences of black girls in classrooms. Youth \& Society, 38(4), 490-515. https://doi.org/10.1177/0044118X06296778.

Morris, M. (2016). Pushout: the criminalization of Black girls in schools. New York, NY: The New Press.

Morris, E. W., \& Perry, B. L. (2017). Girls behaving badly? Race, gender, and subjective evaluation in the discipline of African American girls. Sociology of Education, 90(2), 127-148.

National Women's Law Center. (2014). Unlocking opportunity for African American girls: a call to action for educational equity. Retrieved from http://www.nwlc.org/resource/unlockingopportunity-african-american-girls-call-action-educational-equity

National Women's Law Center. (2017). Let her learn: stopping school pushout for girls of color. https://nwlc.org/wp-content/uploads/ 2017/04/final_nwlc_Gates_GirlsofColor.pdf; NWLC Let Her Learn survey (2017).

National Women's Law Center. (2018). Let Her Learn. Stopping School Pushout for Girls of Color. Available online: https:// nwlcciw49tixgw5lbab.stackpathdns.com/wpcontent/uploads/ 2017/04/final_nwlc_Gates_GirlsofColor.pdf (accessed on 15 June 2020).

Neblett, E., Chavous, T., Nguyên, H., \& Sellers, R. (2009). "Say it loud-I'm Black and I'm proud": Parents' messages about race, racial discrimination, and academic achievement in African American boys. The Journal of Negro Education, 78(3), 246-259. Retrieved from http://www.jstor.org/stable/25608744.

Odafe, M. O., Salami, T. K., \& Walker, R. L. (2017). Race-related stress and hopelessness in community-based African American adults: Moderating role of social support. Cultural Diversity and Ethnic Minority Psychology, 23(4), 561-569. https://doi.org/10. 1037/cdp0000167.

Pizarro, M., \& Kohli, R. (2018). "I stopped sleeping": teachers of color and the impact of racial battle fatigue. Urban Education, 0042085918805788. https://doi.org/10.1177/0042085918805788

Rollins, V. B., \& Valdez, J. N. (2006). Perceived racism and career self-efficacy in African American adolescents. Journal of Black Psychology, 32(2), 176-198. https://doi.org/10.1177/ 0095798406287109.

Rowley, S. J., Ross, L., Lozada, F. T., Williams, A., Gale, A., \& Kurtz-Costes, B. (2014). Framing black boys: parent, teacher, and student narratives of the academic lives of Black boys. In Advances in child development and behavior (pp. 301-332). JAI. https://doi.org/10.1016/bs.acdb.2014.05.003.

Schott Foundation for Public Education. (2015). Black lives matter: The Schott 50 state report on public education and Black males.

Siddle-Walker, V. (2000). Valued segregated schools for African American children in the South, 1935-1969: A review of common themes and characteristics. Review of Educational Research, 70 (3), 253-285.

Smith, W. A., Allen, W. R., \& Danley, L. L. (2007). "Assume the position... you fit the description": psychosocial experiences and racial battle fatigue among African American male GarciaCollege students. American Behavioral Scientist, 51(4), 551-578. https://doi.org/10.1177/0002764207307742.

Smith, W. A., Hung, M., \& Franklin, J. D. (2011a). Racial Battle Fatigue and the MisEducation of Black Men: Racial 
Microaggressions, Societal Problems, and Environmental Stress. The Journal of Negro Education, 80(1), 63-82. http://www.jstor. org/stable/41341106.

Smith, W. A., Yosso, T. J., \& Solórzano, D. G. (2011b). Challenging racial battle fatigue on historically White campuses: A critical race examination of race-related stress. In Covert racism (pp. 211-237). Brill.

Smith, W. A. (2014). Racial battle fatigue in higher education: Exposing the myth of post-racial America. Lanham, MD: Rowman \& Littlefield.

Stevens-Watkins, D., Brown-Wright, L., \& Tyler, K. (2011). Brief report: The number of sexual partners and race-related stress in African American adolescents: Preliminary findings. Journal of Adolescence, 34(1), 191-194. https://doi.org/10.1016/j.adolescence.2010. 02.003 .

Sue, D. W., Capodilupo, C. M., \& Holder, A. M. B. (2008). Racial microaggressions in the life experience of Black Americans. Professional Psychology: Research \& Practice, 39(3), 329-336. https://doi.org/10.1037/0735-7028.39.3.329.

Thomas, D. E., Coard, S. I., Stevenson, H. C., Bentley, K., \& Zamel, P. (2009). Racial and emotional factors predicting teachers' perceptions of classroom behavioral maladjustment for urban African American male youth. Psychology in the Schools, 46(2), 184-196. https://doi.org/10.1002/pits.20362.
Thomas, A. J., Witherspoon, K. M., \& Speight, S. L. (2008). Gendered racism, psychological distress, and coping styles of African American women. Cultural Diversity and Ethnic Minority Psychology, 14(4), 307 https://doi.org/10.1037/10999809.14.4.307.

U.S. Department of Education, National Center for Education Statistics, Schools and Staffing Survey (SASS), "Public school teacher data file," 1987-88 through 2011-12. See Digest of Education Statistics 2013, Table 209.10, Number and percentage distribution of teachers in public and private elementary and secondary schools, by selected teacher characteristics: Selected years, 1987-88 through 2011-12, available at https://nces.ed.gov/progra ms/digest/d13/tables/dt13_209.10.asp.

Williams-Washington, K. N., \& Mills, C. P. (2018). African American historical trauma: Creating an inclusive measure. Journal of Multicultural Counseling and Development, 46(4), 246-263. https://doi.org/10.1080/713667453.

Woodson, A. N. (2020). Don't let me be misunderstood: Psychological safety, Black girls' speech, and Black feminist perspectives on directness. Journal of Educational Psychology, 112(3), 567-578. https://doi.org/10.1037/edu0000458.

Young, M. D., \& Laible, J. (2000). White racism, antiracism, and school leadership preparation. Journal of School Leadership, 10(5), 374-415. https://doi.org/10.1177/105268460001000501. 